\title{
Cellulosimicrobium terreum sp. nov., isolated from soil
}

\author{
Jung-Hoon Yoon, ${ }^{1}$ So-Jung Kang, ${ }^{1}$ Peter Schumann ${ }^{2}$ \\ and Tae-Kwang $\mathrm{Oh}^{1}$
}

Correspondence

Jung-Hoon Yoon

jhyoon@kribb.re.kr

\author{
${ }^{1}$ Korea Research Institute of Bioscience and Biotechnology (KRIBB), PO Box 115, Yusong, \\ Taejon, Korea \\ ${ }^{2} \mathrm{DSMZ}$ - Deutsche Sammlung von Mikroorganismen und Zellkulturen GmbH, Inhoffenstrasse 7b, \\ D-38124 Braunschweig, Germany
}

\begin{abstract}
A Gram-positive, yellow-pigmented, non-motile and rod-shaped or coccoid bacterial strain, DS- $61^{\top}$, was isolated from soil from Dokdo, Korea, and its taxonomic position was investigated by using a polyphasic approach. The strain grew optimally at $\mathrm{pH} 6.5-7.5$ and $25{ }^{\circ} \mathrm{C}$ in the presence of $1.0 \%(\mathrm{w} / \mathrm{v}) \mathrm{NaCl}$. Strain $\mathrm{DS}-61^{\top}$ had peptidoglycan of the type based on L-Lys-L-Thr-D-Asp and contained galactose as the only whole-cell sugar. MK- $9\left(\mathrm{H}_{4}\right)$ was the predominant menaquinone and anteiso- $\mathrm{C}_{15: 0}$ and iso- $\mathrm{C}_{15: 0}$ were the major fatty acids. The major polar lipids were diphosphatidylglycerol, phosphatidylglycerol, phosphatidylinositol and an unidentified phospholipid. The DNA G + C content was 72.9 mol\%. Phylogenetic analyses based on $16 \mathrm{~S}$ rRNA gene sequences showed that strain DS- $61^{\top}$ is most closely affiliated to the genus Cellulosimicrobium, clustering with Cellulosimicrobium cellulans and Cellulosimicrobium funkei. The levels of $16 \mathrm{~S}$ rRNA gene sequence similarity between strain DS- $61^{\top}$ and the type strains of Cellulosimicrobium cellulans and Cellulosimicrobium funkei were 97.4-97.6\%. DNA-DNA relatedness data and differential phenotypic properties demonstrated that strain DS- $61^{\top}$ is distinguishable from these two recognized Cellulosimicrobium species. On the basis of phenotypic, phylogenetic and genetic data, strain DS $-61^{\top}$ represents a novel species of the genus Cellulosimicrobium, for which the name Cellulosimicrobium terreum sp. nov. is proposed. The type strain is DS $-61^{\top}\left(=\right.$ KCTC $\left.19206^{\top}=\mathrm{DSM} 18665^{\top}\right)$. An emended description of the genus is given.
\end{abstract}

The genus Cellulosimicrobium was created by the reclassification of Cellulomonas cellulans as Cellulosimicrobium cellulans (Schumann et al., 2001). Subsequently, two further Cellulosimicrobium species, Cellulosimicrobium variabile (Bakalidou et al., 2002) and Cellulosimicrobium funkei (Brown et al., 2006), were described. However, Cellulosimicrobium variabile was reclassified within a novel genus, Isoptericola, as Isoptericola variabilis (Stackebrandt et al., 2004). In this study, we report on the taxonomic characterization of a bacterial strain, DS- $61^{\mathrm{T}}$, which is phylogenetically closely related to the genus Cellulosimicrobium.

Strain DS-61 ${ }^{\mathrm{T}}$ was isolated from a soil sample collected from Dokdo (37 $14^{\prime} 12^{\prime \prime} \mathrm{N} 131^{\circ} 52^{\prime} 07^{\prime \prime}$ E), Korea, by means of the standard dilution plating technique performed at $25{ }^{\circ} \mathrm{C}$ on $10 \times$ diluted nutrient agar (Difco). Cellulosimicrobium cellulans DSM $43879^{\mathrm{T}}$ and Cellulosimicrobium funkei DSM $16025^{\mathrm{T}}$, which were used as reference

The GenBank/EMBL/DDBJ accession number for the 16S rRNA gene sequence of strain DS- $61^{\top}$ is EF076760. strains, were obtained from the Deutsche Sammlung von Mikroorganismen und Zellkulturen (DSMZ; Braunschweig, Germany). The morphological, physiological and biochemical characteristics of strain DS- $61^{\mathrm{T}}$ were investigated using routine cultivation on trypticase soy agar (TSA; Difco) at $25{ }^{\circ} \mathrm{C}$. The cell morphology was examined by using light microscopy (E600; Nikon) and transmission electron microscopy. Flagellation was determined by using a Philips CM-20 transmission electron microscope with cells from exponentially growing cultures: for this purpose, the cells were negatively stained with $1 \%(\mathrm{w} / \mathrm{v})$ phosphotungstic acid and the grids were examined after being air-dried. The Gram reaction was determined using the bioMérieux Gram stain kit according to the manufacturer's instructions. Growth at various temperatures $\left(4-40{ }^{\circ} \mathrm{C}\right)$ was measured on TSA. Growth in the absence of $\mathrm{NaCl}$ and at various $\mathrm{NaCl}$ concentrations (0.5 and 1.0-10.0\%, w/v, using increments of $1.0 \%$ ) was investigated using trypticase soy broth prepared according to the formula of the Difco medium except that no $\mathrm{NaCl}$ was included. The $\mathrm{pH}$ range for growth was determined in nutrient broth (Difco) that had been 
adjusted, prior to sterilization, to various $\mathrm{pH}$ values ( $\mathrm{pH}$ 4.5-10.5, using increments of $0.5 \mathrm{pH}$ units) by the addition of $\mathrm{HCl}$ or $\mathrm{Na}_{2} \mathrm{CO}_{3}$. Growth under anaerobic conditions was determined after incubation in an anaerobic chamber on TSA and on TSA supplemented with nitrate, both of which had been prepared anaerobically using nitrogen. Catalase and oxidase activities and the hydrolysis of casein, gelatin, hypoxanthine, starch, Tweens 20, 40, 60 and 80 , tyrosine, urea and xanthine were determined as described by Cowan \& Steel (1965). The hydrolysis of aesculin and the reduction of nitrate were determined as described by Lanyi (1987). The utilization of substrates as sole carbon and energy sources was tested according to the method of Kämpfer et al. (1991). Susceptibility to antibiotics was tested on TSA plates using discs containing the following antibiotics: polymyxin B (100 U), streptomycin $(50 \mu \mathrm{g})$, penicillin $\mathrm{G}(20 \mathrm{U})$, chloramphenicol $(100 \mu \mathrm{g})$, ampicillin $(10 \mu \mathrm{g})$, cephalothin $(30 \mu \mathrm{g})$, gentamicin $(30 \mu \mathrm{g})$, novobiocin $(5 \mu \mathrm{g})$, tetracycline $(30 \mu \mathrm{g})$, kanamycin $(30 \mu \mathrm{g})$, lincomycin $(15 \mu \mathrm{g})$, oleandomycin $(15 \mu \mathrm{g})$, neomycin $(30 \mu \mathrm{g})$ and carbenicillin $(100 \mu \mathrm{g})$. Other physiological properties and enzyme activities were tested by using the API 20E and API ZYM systems (bioMérieux).

Cell biomass for DNA extraction and for analysis of the cell-wall components, isoprenoid quinones and polar lipids was obtained from cultures grown, with shaking at 150 r.p.m., in trypticase soy broth (Difco) at $25^{\circ} \mathrm{C}$. Chromosomal DNA was isolated and purified according to the method described by Yoon et al. (1996), with the exception that RNase T1 was used in combination with RNase A to minimize contamination with RNA. The $16 \mathrm{~S}$ rRNA gene was amplified by using a PCR with two universal primers, as described previously (Yoon et al., 1998). The sequencing of the amplified 16S rRNA gene and the phylogenetic analysis were performed as described by Yoon et al. (2003). The DNA G+C content was determined according to the method of Tamaoka \& Komagata (1984), with the modification that the DNA was hydrolysed and the resultant nucleotides analysed by reversed-phase HPLC. The presence or absence of diaminopimelic acid in the peptidoglycan was determined according to the method described by Komagata \& Suzuki (1987). Preparation of the cell walls and determination of the peptidoglycan structure were carried out by using the methods of Schleifer \& Kandler (1972) and MacKenzie (1987) with the modification that TLC on cellulose was applied instead of paper chromatography. Whole-cell sugars were determined as described by Komagata \& Suzuki (1987). Isoprenoid quinones were extracted according to the method of Komagata \& Suzuki (1987) and analysed using reversed-phase HPLC and a YMC ODS-A $(250 \times 4.6 \mathrm{~mm})$ column. Polar lipids were extracted according to the procedures described by Minnikin et al. (1984) and were identified by two-dimensional TLC followed by spraying with the appropriate detection reagents (Minnikin et al., 1984; Komagata \& Suzuki, 1987). For fatty acid methyl ester analysis, cell mass of strain DS- $61^{\mathrm{T}}$ was harvested from TSA plates after incubation for 7 days at $25{ }^{\circ} \mathrm{C}$, and cell mass of Cellulosimicrobium cellulans DSM $43879^{\mathrm{T}}$ and Cellulosimicrobium funkei DSM $16025^{\mathrm{T}}$ was harvested from TSA plates after incubation for 3 days at $28{ }^{\circ} \mathrm{C}$. The fatty acid methyl esters were extracted and prepared according to the standard protocol of the MIDI/Hewlett Packard Microbial Identification System (Sasser, 1990). DNA-DNA hybridization was performed fluorometrically according to the method of Ezaki et al. (1989), using photobiotinlabelled DNA probes and microdilution wells. Hybridization was performed using five replications for each sample: the highest and lowest values obtained in each sample were excluded and the means of the remaining three values were quoted as the DNA-DNA relatedness values.

Morphological, cultural, physiological and biochemical characteristics of strain DS- $61^{\mathrm{T}}$ are given in the species description (see below) or are shown in Table 1. The almost-complete $16 \mathrm{~S}$ rRNA gene sequence of strain DS- $61^{\mathrm{T}}$ determined in this study comprised $1478 \mathrm{nt}$, representing approximately $96 \%$ of the Escherichia coli 16S rRNA gene sequence. In the phylogenetic tree based on the neighbour-joining algorithm, strain DS- $61^{\mathrm{T}}$ joined the cluster comprising Cellulosimicrobium cellulans and Cellulosimicrobium funkei with a bootstrap confidence value of $94.9 \%$ (Fig. 1). The relationship between strain DS- $61^{\mathrm{T}}$ and these two Cellulosimicrobium species was also recovered in trees based on the maximum-likelihood and maximum-parsimony algorithms (Fig. 1). Strain DS- $61^{\mathrm{T}}$ exhibited 16S rRNA gene sequence similarity values of 97.4 and $97.6 \%$ with respect to the type strains of Cellulosimicrobium cellulans and Cellulosimicrobium funkei, respectively.

Quantitative analysis of the peptidoglycan amino acids in the total hydrolysate, determined using gas chromatography according to MacKenzie (1987), showed that strain DS- $61^{\mathrm{T}}$ contained lysine, alanine, threonine, aspartic acid and glutamic acid in the approximate ratio $0.5: 3.4: 0.7: 1.0: 1.0$. The reduced amounts of lysine and threonine are due to the occurrence of the stable peptide LLys-L-Thr. Under more extreme conditions $\left(120^{\circ} \mathrm{C}, 6 \mathrm{M}\right.$ $\mathrm{HCl}, 16 \mathrm{~h}$ ), the peptidoglycan of strain DS- $61^{\mathrm{T}}$ contained lysine, alanine, threonine, aspartic acid and glutamic acid in the approximate ratio $0.9: 2.4: 1.0: 1.0: 1.0$. From these data, it was concluded that strain DS- $61^{\mathrm{T}}$ contains peptidoglycan of the A4 $\alpha$ type, based on L-Lys-L-Thr-DAsp, as described by Schleifer \& Kandler (1972). Galactose was the only whole-cell sugar detected in strain DS- $61^{\mathrm{T}}$. The predominant isoprenoid quinone detected in strain DS- $61^{\mathrm{T}}$ was a tetrahydrogenated menaquinone with nine isoprene units [MK-9 $\left.\left(\mathrm{H}_{4}\right)\right]$. The fatty acid profile of strain DS- $61^{\mathrm{T}}$ comprised large amounts of straight-chain and branched fatty acids; the major components $(>10 \%$ of total fatty acids) were anteiso- $\mathrm{C}_{15: 0}$ and iso- $\mathrm{C}_{15: 0}$ (Table 2). The major polar lipids detected in strain DS- $61^{\mathrm{T}}$ were diphosphatidylglycerol, phosphatidylglycerol, 
Table 1. Differential phenotypic characteristics of strain DS-61 $1^{\top}$ (Cellulosimicrobium terreum sp. nov.) and Cellulosimicrobium cellulans and Cellulosimicrobium funkei

Taxa: 1, strain DS-61 ${ }^{\mathrm{T}} ; 2$, Cellulosimicrobium cellulans; 3, Cellulosimicrobium funkei. Data are from Schumann et al. (2001), Brown et al. (2006) and this study. All are positive for the following: Gram-staining; catalase; hydrolysis of aesculin (not determined for Cellulosimicrobium cellulans), casein, hypoxanthine, starch (not determined for Cellulosimicrobium funkei) and xanthine; acid production from D-glucose and sucrose; utilization of D-glucose, D-fructose (not determined for Cellulosimicrobium cellulans), D-galactose (not determined for Cellulosimicrobium cellulans), Dcellobiose, D-mannose, trehalose (not determined for Cellulosimicrobium cellulans), D-xylose, L-arabinose, sucrose, maltose, acetate (not determined for Cellulosimicrobium funkei), pyruvate (not determined for Cellulosimicrobium funkei) and salicin (not determined for Cellulosimicrobium cellulans) (utilization data for Cellulosimicrobium funkei are from the type strain in this study); alkaline phosphatase, esterase (C4), esterase lipase (C8), acid phosphatase, naphthol-AS-BI-phosphohydrolase and $\alpha$-glucosidase. All are negative for the following: hydrolysis of tyrosine; acid production from L-rhamnose, D-mannitol, inositol and D-sorbitol; utilization of citrate (not determined for Cellulosimicrobium cellulans) and Lmalate (utilization data for Cellulosimicrobium funkei are from the type strain in this study); lipase (C14), leucine arylamidase, valine arylamidase, cystine arylamidase, trypsin, $\alpha$-chymotrypsin, $\alpha$-galactosidase, $\beta$-glucuronidase, $\alpha$-mannosidase and $\alpha$-fucosidase. Data in parentheses are for the type strain. +, Positive reaction; -, negative reaction; $\mathrm{w}$, weakly positive reaction; $\mathrm{v}$, variable reaction; ND, not determined.

\begin{tabular}{|c|c|c|c|}
\hline Characteristic & 1 & 2 & 3 \\
\hline Motility & - & - & + \\
\hline Growth at $35{ }^{\circ} \mathrm{C}$ & - & + & + \\
\hline \multicolumn{4}{|l|}{ Hydrolysis of: } \\
\hline Gelatin & - & + & + \\
\hline Melibiose & - & + & $\mathrm{v}(-)$ \\
\hline L-Arabinose & + & + & $\mathrm{v}(+)$ \\
\hline \multicolumn{4}{|l|}{ API ZYM*: } \\
\hline$\beta$-Galactosidase & - & + & + \\
\hline$\beta$-Glucosidase & - & - & $\mathrm{w}$ \\
\hline DNA G $+C$ content $(\mathrm{mol} \%)$ & 72.9 & $74\left(T_{\mathrm{m}}\right)$ & $74.5\left(T_{\mathrm{m}}\right)$ \\
\hline
\end{tabular}

${ }^{\star}$ Data for Cellulosimicrobium cellulans and Cellulosimicrobium funkei are from the type strains in this study.

phosphatidylinositol and an unidentified phospholipid. These fatty acid and polar lipid profiles were similar to those of Cellulosimicrobium species (Schumann et al., 2001; Stackebrandt et al., 2004; Brown et al., 2006). The DNA $\mathrm{G}+\mathrm{C}$ content of strain DS- $61^{\mathrm{T}}$ was $72.9 \mathrm{~mol} \%$.

Strain DS- $61^{\mathrm{T}}$ is most closely related phylogenetically to the genus Cellulosimicrobium (Fig. 1). There are no distinct phenotypic, particularly chemotaxonomic, properties that serve to differentiate strain DS-61 ${ }^{\mathrm{T}}$ from the genus Cellulosimicrobium (Schumann et al., 2001; Brown et al., 2006). Accordingly, it is appropriate to place strain DS-61 ${ }^{\mathrm{T}}$ within the genus Cellulosimicrobium on the basis of phylogenetic and chemotaxonomic relatedness (Schumann et al., 2001; Brown et al., 2006). Strain DS-61 ${ }^{\mathrm{T}}$ exhibited mean DNA-DNA relatedness values of 19 and $15 \%$ with respect to Cellulosimicrobium cellulans DSM $43879^{\mathrm{T}}$ and Cellulosimicrobium funkei DSM $16025^{\mathrm{T}}$, respectively. Strain DS-6 $1^{\mathrm{T}}$ differs from these two recognized Cellulosimicrobium species in some phenotypic respects, as shown in Table 1. The phylogenetic and genetic distinctiveness and differential phenotypic properties of DS-61 ${ }^{\mathrm{T}}$ are sufficient to categorize it as a member of a species that is distinct from these two recognized Cellulosimicrobium species (Wayne et al., 1987; Stackebrandt \& Goebel, 1994). On the basis of the data presented, strain DS- $61^{\mathrm{T}}$ represents a novel species of the genus Cellulosimicrobium, for which the name Cellulosimicrobium terreum sp. nov. is proposed.

\section{Emended description of the genus Cellulosimicrobium Schumann et al. 2001}

The description of the genus Cellulosimicrobium is as given by Schumann et al. (2001) and Brown et al. (2006), but with the following amendments. The cell-wall peptidoglycan type is A4 $\alpha$, based on L-Lys-D-Ser-D-Asp or L-LysL-Thr-D-Asp. The DNA G $+\mathrm{C}$ contents are in the range 72.9-74.5 mol\%. 


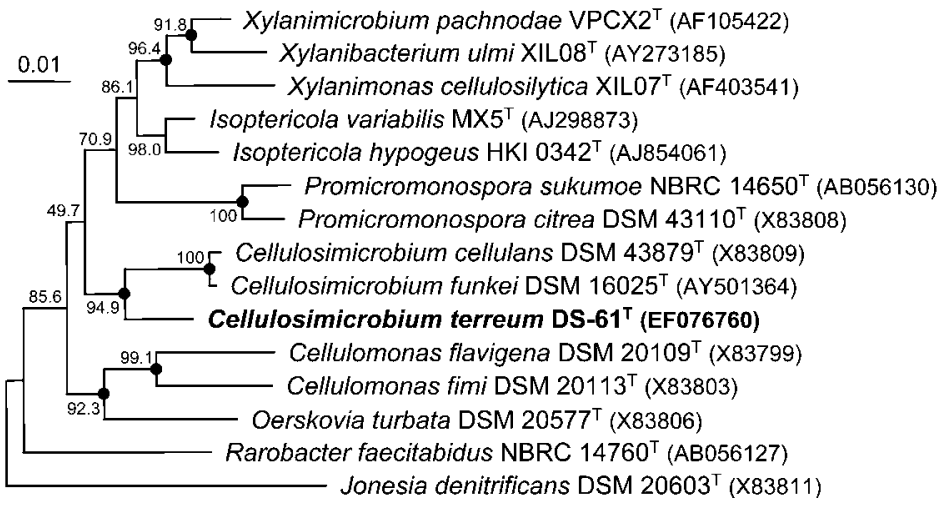

Fig. 1. Neighbour-joining phylogenetic tree, based on 16S rRNA gene sequences, showing the positions of strain DS- $61^{\top}$ and some related taxa. Bootstrap percentages (based on 1000 replications) are shown at branch points. Jonesia denitrificans DSM $20603^{\top}$ (GenBank accession number X83811) was used as an outgroup. Filled circles indicate that the corresponding nodes were also recovered in the trees generated with the maximumlikelihood and maximum-parsimony algorithms. Bar, 0.01 substitutions per nucleotide position.

\section{Description of Cellulosimicrobium terreum sp. nov.}

Cellulosimicrobium terreum (ter're.um. L. neut. adj. terreum of the earth).

Cells are Gram-positive, non-spore-forming rods or cocci $(0.4-0.8 \times 0.4-2.0 \mu \mathrm{m})$; in older cultures, cells are Gramvariable and most cells are cocci. Colonies on TSA are circular, convex, smooth, glistening, yellow in colour and $1.5-2.0 \mathrm{~mm}$ in diameter after 7 days incubation at $25^{\circ} \mathrm{C}$. Substrate hyphae are present. Optimal temperature for growth is $25^{\circ} \mathrm{C}$. Growth occurs at 4 and $34{ }^{\circ} \mathrm{C}$, but not at $35{ }^{\circ} \mathrm{C}$. Optimal $\mathrm{pH}$ for growth is $6.5-7.5$; growth occurs at $\mathrm{pH} 6.0$ and 9.0, but not at $\mathrm{pH} 5.5$ or 9.5. Growth occurs in the presence of $0-9 \%(\mathrm{w} / \mathrm{v}) \mathrm{NaCl}$; optimal growth occurs in the presence of $1.0 \%(\mathrm{w} / \mathrm{v}) \mathrm{NaCl}$. Anaerobic growth does not occur on TSA or on TSA supplemented with nitrate. Oxidase-negative. Tweens 20, 40, 60 and 80 are

Table 2. Cellular fatty acid compositions (\%) for strain DS$61^{\top}$ and Cellulosimicrobium cellulans and Cellulosimicrobium funkei

Strains: 1, DS-61 ${ }^{\mathrm{T}}$; 2, Cellulosimicrobium cellulans DSM $43879^{\mathrm{T}}$; 3, Cellulosimicrobium funkei DSM $16025^{\mathrm{T}}$. Data are from this study. Fatty acids that represented $<0.5 \%$ in the three strains have been omitted.

\begin{tabular}{|c|c|c|c|}
\hline Fatty acid & 1 & 2 & 3 \\
\hline \multicolumn{4}{|c|}{ Straight-chain fatty acids } \\
\hline $\mathrm{C}_{14: 0}$ & 3.3 & 4.6 & 1.9 \\
\hline $\mathrm{C}_{15: 0}$ & 1.3 & 1.1 & 1.0 \\
\hline $\mathrm{C}_{16: 0}$ & 5.5 & 6.9 & 6.6 \\
\hline $\mathrm{C}_{18: 0}$ & 0.6 & 0.3 & 0.2 \\
\hline \multicolumn{4}{|c|}{ Branched fatty acids } \\
\hline iso- $\mathrm{C}_{14: 0}$ & 4.0 & 2.8 & 0.4 \\
\hline iso- $\mathrm{C}_{15: 0}$ & 14.5 & 16.5 & 21.9 \\
\hline anteiso- $\mathrm{C}_{15: 0}$ & 52.5 & 35.7 & 44.4 \\
\hline iso- $\mathrm{C}_{16: 0}$ & 8.4 & 12.1 & 5.3 \\
\hline iso- $\mathrm{C}_{17: 0}$ & 0.8 & 4.5 & 2.9 \\
\hline anteiso- $\mathrm{C}_{17: 0}$ & 7.8 & 14.8 & 15.1 \\
\hline
\end{tabular}

hydrolysed. $\mathrm{H}_{2} \mathrm{~S}$ and indole are not produced. L-Glutamate is utilized as a sole carbon and energy source, but succinate, benzoate and formate are not. Arginine dihydrolase, lysine decarboxylase, ornithine decarboxylase and tryptophan deaminase are absent. Susceptible to cephalothin, chloramphenicol, neomycin, novobiocin, oleandomycin, penicillin G, streptomycin and tetracycline, but not to carbenicillin, gentamicin, kanamycin, lincomycin or polymyxin B. The cell-wall peptidoglycan type is L-Lys-L-ThrD-Asp. The only whole-cell sugar is galactose. The predominant menaquinone is MK- $9\left(\mathrm{H}_{4}\right)$. Major fatty acids are anteiso- $\mathrm{C}_{15: 0}$ and iso- $\mathrm{C}_{15: 0}$. Major polar lipids are diphosphatidylglycerol, phosphatidylglycerol, phosphatidylinositol and an unidentified phospholipid. The DNA $\mathrm{G}+\mathrm{C}$ content of the type strain is $72.9 \mathrm{~mol} \%$ (determined by HPLC). Other phenotypic characteristics are given in Table 1.

The type strain, DS-61 ${ }^{\mathrm{T}}\left(=\mathrm{KCTC} 19206^{\mathrm{T}}=\mathrm{DSM} 18665^{\mathrm{T}}\right)$, was isolated from soil from Dokdo, Korea.

\section{Acknowledgements}

This work was supported by the 21C Frontier Program of Microbial Genomics and Applications (grant MG05-0401-2-0) from the Ministry of Science and Technology (MOST) of the Republic of Korea.

\section{References}

Bakalidou, A., Kämpfer, P., Berchtold, M., Kuhnigk, T., Wenzel, M. \& König, H. (2002). Cellulosimicrobium variabile sp. nov., a cellulolytic bacterium from the hindgut of the termite Mastotermes darwiniensis. Int J Syst Evol Microbiol 52, 1185-1192.

Brown, J. M., Steigerwalt, A. G., Morey, R. E., Daneshvar, M. I. Romero, L.-J. \& McNeil, M. M. (2006). Characterization of clinical isolates previously identified as Oerskovia turbata: proposal of Cellulosimicrobium funkei sp. nov. and emended description of the genus Cellulosimicrobium. Int J Syst Evol Microbiol 56, 801-804.

Cowan, S. T. \& Steel, K. J. (1965). Manual for the Identification of Medical Bacteria. London: Cambridge University Press.

Ezaki, T., Hashimoto, Y. \& Yabuuchi, E. (1989). Fluorometric deoxyribonucleic acid-deoxyribonucleic acid hybridization in microdilution wells as an alternative to membrane filter hybridization in 
which radioisotopes are used to determine genetic relatedness among bacterial strains. Int J Syst Bacteriol 39, 224-229.

Kämpfer, P., Steiof, M. \& Dott, W. (1991). Microbiological characterization of a fuel-oil contaminated site including numerical identification of heterotrophic water and soil bacteria. Microb Ecol 21, 227-251.

Komagata, K. \& Suzuki, K. (1987). Lipid and cell-wall analysis in bacterial systematics. Methods Microbiol 19, 161-203.

Lanyi, B. (1987). Classical and rapid identification methods for medically important bacteria. Methods Microbiol 19, 1-67.

MacKenzie, S. L. (1987). Gas chromatographic analysis of amino acids as the $N$-heptafluorobutyryl isobutyl esters. J Assoc Off Anal Chem 70, 151-160.

Minnikin, D. E., O’Donnell, A. G., Goodfellow, M., Alderson, G., Athalye, M., Schaal, A. \& Parlett, J. H. (1984). An integrated procedure for the extraction of bacterial isoprenoid quinones and polar lipids. J Microbiol Methods 2, 233-241.

Sasser, M. (1990). Identification of bacteria by gas chromatography of cellular fatty acids, MIDI Technical Note 101. Newark, DE: MIDI Inc.

Schleifer, K. H. \& Kandler, O. (1972). Peptidoglycan types of bacterial cell walls and their taxonomic implications. Bacteriol Rev 36, 407-477.

Schumann, P., Weiss, N. \& Stackebrandt, E. (2001). Reclassification of Cellulomonas cellulans (Stackebrandt and Keddie 1986) as Cellulosimicrobium cellulans gen. nov., comb. nov. Int J Syst Evol Microbiol 51, 1007-1010.
Stackebrandt, E. \& Goebel, B. M. (1994). Taxonomic note: a place for DNA-DNA reassociation and $16 \mathrm{~S}$ rRNA sequence analysis in the present species definition in bacteriology. Int J Syst Bacteriol 44, 846849.

Stackebrandt, E., Schumann, P. \& Cui, X.-L. (2004). Reclassification of Cellulosimicrobium variabile Bakalidou et al. 2002 as Isoptericola variabilis gen. nov., comb. nov. Int J Syst Evol Microbiol 54, 685-688.

Tamaoka, J. \& Komagata, K. (1984). Determination of DNA base composition by reversed-phase high-performance liquid chromatography. FEMS Microbiol Lett 25, 125-128.

Wayne, L. G., Brenner, D. J., Colwell, R. R., Grimont, P. A. D., Kandler, O., Krichevsky, M. I., Moore, L. H., Moore, W. E. C., Murray, R. G. E. \& other authors (1987). International Committee on Systematic Bacteriology. Report of the ad hoc committee on reconciliation of approaches to bacterial systematics. Int J Syst Bacteriol 37, 463-464.

Yoon, J.-H., Kim, H., Kim, S.-B., Kim, H.-J., Kim, W. Y., Lee, S. T., Goodfellow, M. \& Park, Y.-H. (1996). Identification of Saccharomonospora strains by the use of genomic DNA fragments and rRNA gene probes. Int J Syst Bacteriol 46, 502-505.

Yoon, J.-H., Lee, S. T. \& Park, Y.-H. (1998). Inter- and intraspecific phylogenetic analysis of the genus Nocardioides and related taxa based on 16S rRNA gene sequences. Int J Syst Bacteriol 48, 187-194.

Yoon, J.-H., Kang, K. H. \& Park, Y.-H. (2003). Psychrobacter jeotgali sp. nov., isolated from jeotgal, a traditional Korean fermented seafood. Int J Syst Evol Microbiol 53, 449-454. 